\title{
MODEL PENDIDIKAN KARAKTER DI MASYARAKAT
}

\author{
Agus Supian \\ Mahasiswa Pascasarjana Program S2 UIN SGD Bandung \\ e-mail:agussupian@gmail.com
}

\begin{abstract}
Abstrak
Penelitian ini bertujuan untuk mengkaji mengenai pengembangan model pendidikan karakter di masyarakat. Penelitian ini menggunakan metode kepustakaan atau library research, yakni penelitian yang dilakukan melalui pengumpulan data atau karya tulis ilmiah dengan objek penelitian atau pengumpulan data bersifat kepustakaan. Hasil analisis menunjukkan, bahwa Karakter merupakan cara berpikir dan berprilaku yang menjadi ciri khas tiap individu untuk hidup dan bekerjasama, baik dalam lingkup keluarga, masyarakat, bangsa, dan negara. Nilai-nilai dalam pendidikan karakter berbasis masyarakat dapat bersumber dari agama, Pancasila, budaya, dan tujuan pendidikan nasional. Adapun pengembangan Model yang dapat digunakan dalam praktik pendidikan karakter di masyarakat khususnya di Institusi Pemerintah, Institusi Sosial , dan di Ruang-ruang Publik, yaitu model pendidikan melalui proses pengajaran, keteladanan, pembiasaan, pemotivasian, serta penegakan aturan.
\end{abstract}

\section{Kata Kunci: model pendidikan karakter di masyarakat}

\section{Abstract}

This study aims to examine the development of a character education model in society. This research uses the library research method, which is research conducted through data collection or scientific writing with the object of research or library data collection. The results of the analysis show that character is a way of thinking and behaving that is characteristic of each individual to live and work together, both within the sphere of family, society, nation and state. Values in community-based character education can come from religion, Pancasila, culture, and the goals of national education. The development of a model that can be used in the practice of character education in society, especially in government institutions, social institutions, and in public spaces, is a model of education through the process of teaching, modeling, and habituation, motivating, and enforcing rules.

Keywords: character education model in society

\section{PENDAHULUAN}

Karakter merupakan hal yang sangat penting dan mendasar. Penguatan pendidikan karakter dalam konteks sekarang menjadi sangat relevan untuk mengatasi krisis moral yang sedang terjadi di negara kita. Bangsa kita belakangan ini menunjukkan gejala kemerosotan moral yang amat sangat parah, mulai dari kasus narkoba, kasus korupsi, ketidakadilan hukum, pergaulan bebas dikalangan remaja, pelajar bahkan mahasiswa, maraknya kekerasan, kerusuhan, tindakan anarkis, dan sebagainya, mengindikasi adanya pergeseran kearah ketidakpastian jati diri dan karakter bangsa (Syamsul Kurniawan, 2013)

Kekuatan karakter yang dibentuk dalam lingkungan keluarga, sekolah, dan perguruan tinggi akan semakin baik jika ada dukungan dan dorongan dari lingkungan masyarakat sekitar. Masyarakat sebagai lingkungan pendidikan yang lebih luas turut berperan dalam terselenggaranya proses pendidikan karakter.Satuan pendidikan dapat bekerjasama dengan masyarakat sekitar 
untuk mencapai 5 kristalisasi nilai karakter, misalnya mengadakan sosialisasi mengenai bahaya narkoba dari Kepolisian sehingga peserta didik mengetahui bahaya dari narkoba. Berpijak dari tanggungjawab tersebut, lingkungan masyarakat yang baik dapat melahirkan berbagai kegiatan masyarakat yang mendukung tumbuh kembangnya karakter. Di Indonesia dikenaladanya konsep pendidikan berbasis masyarakat sebagai upaya untuk memberdayakan masyarakat dalam penyelenggaraan pendidikan (Syamsul Kurniawan, 2013).

Berbagai studi yang terkait dengan peran masyarakat dalam pendidikan menunjukkan bahwa keberhasilan pendidikan, dalam hal ini pendidikan karakter, bergantung pada kemitraan yang sinergis di antara para pelaku pendidikan, yakni keluarga, sekolah, dan masyarakat. Fondasi pendidikan karakter sebagaimana digaris bawahi oleh Ki Hajar Dewantara dilaksanakan oleh keluarga sebagai pendidik yang pertama dan utama.Namun, lingkungan masyarakat juga sangat memengaruhi keberhasilannya. Praktik baik kolaborasi antar anggota masyarakat telah menjadi bagian dari tradisi Indonesia melalui semangat gotong royong. Kepedulian menjadi kata kunci dalam keberhasilan pendidikan karakter. Sekaranglah saatnya untuk melakukan penguatan pendidikan karakter yang berbasis komunitas/masyarakat.

Kemitraan trisentra pendidikan yang terdiri atas satuan pendidikan, keluarga, dan masyarakat dalam membangun ekosistem pendidikan sejalan dengan visi Kementerian Pendidikan dan Kebudayaan (Kemendikbud), yaitu "Terbentuknya insan serta ekosistem pendidikan dan kebudayaan yang berkarakter dengan berlandaskan gotong royong". Komite Sekolah mempunyai peran besar dalam kemitraan ini termasuk dalam upaya penguatan pendidikan karakter yang dilakukan untuk menyiapkan Generasi Emas 2045.

Makalah sederhana ini akan mencoba menelaah mengenai pengembangan model pendidikan karakter di masyarakat, Maka dari itu diperlukan komitmen antara guru, wali murid, dan masyarakat terhadap aturan-aturan yang sudah disepakati.

\section{METODOLOGI}

Penelitian ini menggunakan pendekatan kualitatif dengan jenis penelitian kepustakaan (library research) yaitu dengan mengumpulkan data-data dan bahan-bahan yang berkaitan dengan tema pembahasannya. penelitian ini adalah subjek dari mana data tersebut diperoleh. Dalam penelitian ini yang menjadi sumber data adalah: Pertama, sumber data primer, maksudnya sumber-sumber yang memberikan data secara langsung dari tangan pertama atau merupakan sumber asli. Dalam penelitian ini yang menjadi sumber datanya berupa buku, jurnal, majalah, dll. Kedua, sumber data sekunder, yaitu sumber-sumber lain yang diperoleh dari sumber primer. Dalam penelitian ini sumber data sekunder berupa buku-buku lain yang berhubungan dengan bahasan penelitian ini. Setelah keseluruhan data terkumpul, maka langkah selanjutnya penulis menganalisa data tersebut sehingga ditarik suatu kesimpulan. Untuk memperoleh hasil yang benar dan tepat dalam menganalisa data, penulis menggunakan teknik analisis isi. Analisis isi (Content Analysis) adalah penelitian yang bersifat informasi tertulis atau tercetak di media massa.

\section{HASIL DAN PEMBAHASAN}

\section{Definisi Pendidikan Karakter Berbasis Masyarakat}

Karakter menurut Suyanto adalah cara berpikir dan berprilaku yang menjadi ciri khas tiap individu untuk hidup dan bekerjasama, baik dalam lingkup keluarga, masyarakat, bangsa, dan negara (Masnur Muslich, 2011). Sedangkan pendidikan karakter menurut Ratna Megawangi adalah sebuah usaha untuk mendidik anak-anak agar dapat mengambil keputusan dengan bijak dan mempraktikannya dalam kehidupan seharihari, sehingga mereka dapat memberikan kontribusi yang positif kepada lingkungannya (Dharma, 2011). Jadi dapat dikatakan bahwa pendidikan karakter merupakan usaha dalam 
mendidik anak-anak agar dapat berpikir dan bertindak secara bijaksana, baik dalam lingkup keluarga, masyarakat, maupun bangsa. Maka pendidikan karakter berbasis masyarakat mempunyai peranan yang sangat penting guna menunjang pendidikan di sekolah.

Istilah pendidikan berbasis masyarakat pada awalnya diperkenalkan oleh Comton and Mc Clusky dengan menggunakan istilah community education for development, yang diartikan sebagai sebuah proses dimana setiap anggota masyarakat hadir untuk mengemukakan setiap persoalan dan kebutuhan, mencari solusi di antara mereka, mengerahkan sumber daya yang tersedia dan melaksanakan suatu rencana kegiatan atau pembelajaran atau keduanya.

Pendidikan berbasis masyarakat (Community based education) adalah sebuah model pendidikan yang mengikutsertakan masyarakat di dalam penyelenggaraan dan pengelolaan pendidikan, maka pendidikan tersebut berakar dari masyarakat dan di dalam kebudayaan (H.AR Tilaar, 2000). Pendidikan berbasis masyarakat merupakan pendidikan yang dirancang oleh masyarakat untuk membelajarkan masyarakat sehingga mereka berdaya, dalam arti memiliki kekuatan untuk membangun dirinya sendiri yang sudah barang tentu melalui interaksi dengan lingkungannya.

Dengan demikian konsep pendidikan berbasis masyarakat mencakup: dari masyarakat, oleh masyarakat dan untuk masyarakat (Umberto Sihombing, 2001). Pendidikan dari masyarakat artinya pendidikan merupakan jawaban terhadap apa yang menjadi kebutuhan masyarakat. Pendidikan oleh masyarakat artinya masyarakat merupakan pelaku atau subyek pendidikan yang aktif, bukan hanya sekadar obyek pendidikan. Pendidikan untuk masyarakat artinya masyarakat diikutsertakan dalam semua program yang dirancang untuk menjawab kebutuhan mereka (Wahyudin Sumpeno, 2009).

Berdasarkan konsep di atas, dapat diketahui bahwa pendidikan karakter berbasis masyarakat adalah pendidikan yang dikelola oleh masyarakat, baik berbentuk formal maupun informal dengan memanfaatkan fasilitas yang ada menekankan pentingnya partisipasi masyarakat yang bertujuan untuk menanamkan nilai-nilai dan karakter yang baik, sehingga mampu menjawab kebutuhan masyarakat.

\section{Tujuan Pendidikan Karakter Berbasis Masyarakat}

Pendidikan berbasis masyarakat lebih diarahkan untuk membentuk disposisi mental dan emosional, mensosialisasikan pemaknaan dan mengajarkan peserta didik ilmu pengetahuan sebagai strategi dalam menyongsong masa depan. Pendidikan berbasis masyarakat tidak hanya menuntut adanya keterlibatan dan peran aktif masyarakat, tetapi hasil dari penyelenggaraan pendidikan, dituntut untuk mampu memecahkan berbagai macam problematika masyarakat (Bagong Suyanto, 200511). Berdasarkan hal diatas, maka dapat diketahui bahwa usaha sekolah dalam mengajarkan nilai dan karakter kepada peserta didik membutuhkan partisipasi dari masyarakat.

Pendidikan Karakter perlu dikembangkan di masyarakast. Sebagai upaya untuk meningkatkan kesesuaian dan mutu pendidikan karakter, Kementerian Pendidikan Nasional mengembangkan grand design pendidikan karakter untuk setiap jalur, jenjang, dan jenis satuan pendidikan. Grand design menjadi rujukan konseptual dan operasional pengembangan, pelaksanaan, dan penilaian pada setiap jalur dan jenjang pendidikan. Adapun acuan konfigurasi karakter dalam konteks totalitas proses psikologis dan sosial-kultural tersebut dikelompokan sebagaimana uraian berikut.

a. Olah Hati (Spiritual and emotional development). Olah hati bermuara pada pengelolaanspiritual dan emosional.
b. Olah Pikir (intellectual development). Olah pikir bermuara pada pengelolaanintelektual.

c. Olah Raga dan Kinestetik (Physical and kinestetic development). Olah raga bermuarapada pengelolaan fisik.

d. Olah Rasa dan Karsa (Affective and Creativity development). Olah rasa 
bermuara pada pengelolaan kreativitas (Aan Hasanah, 2013).

Pengembangan pendidikan karakter bisa menggunakan kurikulum berkarakter atau "Kurikulum Holistik Berbasis Karakter" (Character-based Integrated Curriculum). Kurikulum ini merupakan kurikulum terpadu yang menyentuh semua aspek kebutuhan anak. Sebuah kurikulum yang terkait, tidak terkotak-kotak dan dapat merefleksikan dimensi, keterampilan, dengan menampilkan tema-tema yang menarik dan kontekstual. Bidang-bidang pengembangan yang ada di masyarakat yang dikembangkan dalam konsep pendidikan kecakapan hidup yang terkait dengan pendidikan personal dan sosial, pengembangan berpikir/kognitif, pengembangan karakter dan pengembangan persepsi motoric juga dapat tersusun dengan baik apabila materi ajarnya dirancang melalui pembelajaran yang terpadu dan menyeluruh (Holistik).

\section{Prinsip-prinsip Pendidikan Karakter Berbasis Masyarakat}

Menurut Michael W. Galbraith, pendidikan berbasis masyarakat memiliki beberapa prinsip, diantaranya adalah:

a. Self determination (menentukan sendiri)

Setiap anggota masyarakat memiliki hak dan tanggung jawab untuk terlibat dalam menentukan kebutuhan masyarakat.

b. Self help (menolong sendiri)

Masyarakat didorong untuk menolong diri mereka sendiri, mereka menjadi bagian dari solusi dan membangun kemandirian.

c. Leadership development (pengembangan kepemimpinan)

Pemimpin lokal memiliki kemampuan untuk memecahkan masalah, mengambil keputusan, dan memandirikan kelompok untuk mengembangkan masyarakat secara berkesinambungan.

d. Localization (lokalitas)

Partisipasi masyarakat akan berjalan secara maksimal apabila masyarakat mendapatkan kesempatan untuk terlibat dalam program- program yang ada dilingkungan tempat tinggalnya.

e. Integred delivery of service (keterpaduan pemberian layanan)

Setiap organisasi yang ada dalam masyarakat secara bersama-sama melayani masyarakat untuk mencapai tujuan yang diinginkan.

f. Reduce duplication of service

(mengurangi duplikasi jasa)

Masyarakat perlu mengkoordinasikan segala bentuk pelayanan, keuangan dan sumber daya manusia untuk menghindari duplikasi (Zubaedi, 2006).

g. Accept diversity (menerima

keaekaragaman)

Pendidikan berbasis masyarakat hendaknya menghindari adanya pemisahan orang-orang disebabkan oleh perbedaan usia, kelas sosial,jenis kelamin, ras, etnik, agama, yang menyebabkan terhalangnya pengembangan masyarakat secara optimal.

h. Institusional responsive (tanggung jawab kelembagaan)

Lembaga pendidikan harus memiliki kepekaan terhadap kebutuhan masyarakat yang selalu berubah.

i. Life long learning (pembelajaran seumur hidup)

Peluang untuk belajar secara formal harus tersedia untuk semua anggota masyarakat dengan beragam latar belakang (Zubaedi, 2006).

Berdasarkan prinsip-prinsip diatas, maka masyarakat juga merasa ikut memiliki dan bertanggung jawab atas kesuksesan dari proses pendidikan tersebut.

\section{Peran Serta Masyarakat Dalam Pendidikan Karakter Berbasis Masyarakat}

Kunci keberhasilan pelaksanaan pendidikan karakter tidak hanya ditentukan oleh keterlibatan orang-orang dalam. Melainkan ia juga ditentukan oleh adanya keterlibatan "orang-orang luar" sekolah. Mereka adalah orang tua siswa dan komunitas karakter. Sekolah perlu menggerakkan mereka agar terlibat secara optimal dalam mewujudkan sekolah karakter (Saptono, 2011).

Maka peran serta masyarakat terhadap 
pengembangan konsep pendidikan berbasis masyarakat dapat dilihat melalui beberapa kriteria, diantaranya sebagaiberikut :

a. Peran serta masyarakat tidak hanya berwujud pemberian bantuan uang atau fisik, tetapi juga hal-hal akademik.

b. Kewajiban sekolah (monitoring dan accountability) yang tinggi terhadap pemerintah maupun masyarakat

c. Memberi kesempatan luas kepada masyarakat untuk berpartisipasi dalam pengelolaan lembaga pendidikan termasuk dalam partisipassi dalam pembuatan keputusan-keputusan

d. Program sekolah disusun dan dilaksanakan dengan mengutamakan kepentingan tujuan pendidikan, bukan hanya untuk kepentingan administratif atau birokrasi.

e. Program pendidikan sesuai dengan kebutuhan masyarakat baik sekarang maupun mendatang, berorientasi pada peningkatan mutu bukan untuk kepentingan birokrasi.

f. Laporan pertanggungjawaban terbuka untuk semua pihak yang berkepentingan (Haris. A.S, 2001).

Dari beberapa kriteria partisipasi masyarakat diatas, maka masyarakat memiliki posisi yang urgen dalam keberlangsungan pelaksanaan pendidikan berbasis masyarakat, dan peran serta yang diambil oleh masyarakat tidak hanya sebagai donatur sekolah tetapi juga meliputi kebijakan-kebijakan yang akan diambil oleh sekolah tersebut dalam pelaksanaan pendidikan tersebut.

\section{Nilai-nilai Dalam Pendidikan Karakter Berbasis Masyarakat.}

Nilai-nilai dalam pendidikan karakter berbasis masyarakat dapat bersumber dari agama, Pancasila, budaya, dan tujuan pendidikan nasional, sebagaimana tabel di bawah ini (Samani, 2011):

Tabel 1

Nilai dan Deskripsi Nilai Pendidkan Karakter Nasional

\begin{tabular}{|c|c|c|}
\hline No & Nilai & Deskripsi Nilai Pendidikan Karakter \\
\hline 1 & Religius & $\begin{array}{l}\text { Sikap dan prilaku yang patuh dalam melaksanakan ajaran agama yang di } \\
\text { anutnya, toleran dalam pelaksanaan ibadah agama lain, hidup rukun } \\
\text { dengan pemeluk agama lain. }\end{array}$ \\
\hline 2 & Jujur & $\begin{array}{l}\text { Perilaku yang didasarkan pada upaya yang menjadikan dirinya dapat } \\
\text { dipercaya dalam perkataan, tindakan, dan } \\
\text { pekerjaan. }\end{array}$ \\
\hline 3 & Toleransi & $\begin{array}{l}\text { Sikap dan toleransi yang menghargai perbedaan agama, suku, etnis, } \\
\text { pendapat, sikap, dan tidakan orang lain yangberbeda dengan dirinya. }\end{array}$ \\
\hline 4 & Disiplin & $\begin{array}{l}\text { Tindakan yang menunjukan prilaku tertib dan patuh pada berbagai } \\
\text { ketentuan dan peraturan. }\end{array}$ \\
\hline 5 & Kerja keras & $\begin{array}{l}\text { Perilaku yang menunjukkan upaya yang sungguh-sungguh dalam } \\
\text { mengatasi berbagai hambatan belajar, serta menyelesaikan tugas sebaik- } \\
\text { baiknya. }\end{array}$ \\
\hline 6 & Kreatif & $\begin{array}{l}\text { Berpikir dan melakukan sesuatu untuk menghasilkan cara atau hasil baru } \\
\text { dari sesuatu yang telah dimiliki. }\end{array}$ \\
\hline 7 & Mandiri & $\begin{array}{l}\text { Sikap yang tidak mudah tergantung pada orang lain dalam menyelesaikan } \\
\text { tugas-tugasnya }\end{array}$ \\
\hline 8 & Demokrats & $\begin{array}{l}\text { Cara berpikir, bersikap, dan bertindak yang menilai sama hak dan } \\
\text { kewajiban dirinya dan orang lain. }\end{array}$ \\
\hline 9 & Rasa Ingin Tahu & $\begin{array}{l}\text { Sikap dan tindakan yang selalu berupaya untuk mengusai lebih dalam } \\
\text { dan luas dari sesuatu yang dipelajarinya, dilihat, dan yang didengar. }\end{array}$ \\
\hline
\end{tabular}




\begin{tabular}{|c|c|c|}
\hline No & Nilai & Deskripsi Nilai Pendidikan Karakter \\
\hline 10 & $\begin{array}{l}\text { Semangat } \\
\text { Kebangsaan }\end{array}$ & $\begin{array}{l}\text { Cara berpikir, bertindak, dan berwawasan yang } \\
\text { menepatkan kepentinganbangsa dan Negara di atas kepenting diri dan } \\
\text { kelompok }\end{array}$ \\
\hline 11 & $\begin{array}{l}\text { Cinta Tanah } \\
\text { Air }\end{array}$ & $\begin{array}{l}\text { Cara berpikir, bersikap, dan perbuatan yang menunjukan kesetiaan dan } \\
\text { kepedulian yang tinggi terhadap bahasa, lingkungan fisik, sosial, budaya, } \\
\text { ekonomi dan politik } \\
\text { bangsa. }\end{array}$ \\
\hline 12 & $\begin{array}{l}\text { Menghargai } \\
\text { Prestasi }\end{array}$ & $\begin{array}{l}\text { Sikap dan tindakan yang mendorong dirinya untuk menghasilkan } \\
\text { sesuatu yang berguna bagi masyarakat, mengakui, serta menghormati } \\
\text { keberhasilan orang lain. }\end{array}$ \\
\hline No & & Deskripsi Nilai Pendidikan Karakter \\
\hline 13 & $\begin{array}{l}\text { Bers } \\
\text { Kom }\end{array}$ & $\begin{array}{l}\text { Tindakan yang memperlihatkan rasa senang berbicara, } \\
\text { bergaul, bekerjasama dengan orang lain. }\end{array}$ \\
\hline 14 & Cinta damai & $\begin{array}{l}\text { Sikap, perkataan, dan tindakan yang menyebabkan orang lain merasa } \\
\text { senang dan aman atas kehadiran dirinya. }\end{array}$ \\
\hline 15 & $\begin{array}{l}\text { Gemar } \\
\text { membaca }\end{array}$ & $\begin{array}{l}\text { Kebiasaan menyediakan waktu untuk membaca berbagai macam bacaan } \\
\text { yang memberikan kebaikan pada dirinya }\end{array}$ \\
\hline 16 & $\begin{array}{l}\text { Pedulli } \\
\text { lingkungan }\end{array}$ & $\begin{array}{l}\text { Sikap dan tidakan yang selalu berupaya kerusakan pada lingkungan alam } \\
\text { disekitranya, bdan mengembangkan upaya-upaya untuk memperbaiki } \\
\text { kerusakan alam yang sudah terjadi. }\end{array}$ \\
\hline 17 & Peduli sosial & $\begin{array}{l}\text { Sikap dan tindakan yang selalu ingin memberikan bantuan terhadap orang } \\
\text { lain dan masyarakat yang selulu membutuhkannya }\end{array}$ \\
\hline 18 & Tanggung jawab & $\begin{array}{l}\text { Sikap dan prilaku seseorang yang selalu melaksanakan tugas dan } \\
\text { kewajiban, yang seharusnya dilakukan terhadap diri sendiri, masyarakat, } \\
\text { lingkungan, Negara, dan tuhan yang maha Esa. }\end{array}$ \\
\hline
\end{tabular}

\section{Model Pendidikan Karakter di Masyarakat}

Secara umum istilah model diartikan sebagai kerangka konseptual yang digunakan sebagai pedoman dalam melakukan suatu kegiatan. Dalam pengertian lain, model juga diartikan sebagai barang atau benda tiruan dari benda yang sesungguhnya. Model adalah contoh, pola, acuan, ragam, macam, dan sebagainya yang dibuat menurut aslinya. Model juga diartikan sebagai barang tiruan yang kecil dan tepat seperti yang ditiru, contohnya model pesawat terbang.

Menurut Abdul Majid dan Dian Andayani, model adalah barang atau benda tiruan dari benda yang sesungguhnya, seperti, globe (bola dunia) adalah model dari bumi tempat kita hidup. Menurut Muhaimin, model merupakan kerangka konseptual yang dipergunakan sebagai pedoman atau acuan dalam melakukan suatu kegiatan. Model juga merupakan seperangkat prosedur yang sistematis untuk mewujudkan suatu proses kegiatan. Sementara menurut Dedhi Suharto, model adalah suatu yang dapat memvisualisasikan sebuah konsep dengan nyata. Model berbeda dengan konsep dalam bentuk teori. Fungsi model adalah menjembatani konsep dalam bentuk teori menjadi kenyataan (Amirulloh Syarbini, 2017).

Dari beberapa definisi di atas dapat dipahami bahwa model adalah kerangka konseptual atau prosedur yang sistematis mengenai suatu hal yang berfungsi sebagai pedoman atau contoh bagi pihak lain yang ingin mengikutinya. Berikut ini beberapa gambaran bagaimana penerapan model dalam pendidikan karakter di masyarakat, yaitu : 
1). Segala sesuatu yang ada di sekolah terorganisasikan di seputar hubungan antar siswa dan antara siswa dan guru beserta staf dan komunitas di sekitarnya.

2). Sekolah merupakan komunitas yang peduli (Caring Community) di mana terdapat ikatan yang kuat dan menghubungkan siswa dengan guru, staf, dan sekolah.

3). Pembelajaran sosial dan pembelajaran emosi juga dikembangkan sebagaimana pembelajaran akademik.

4). Kooperasi dan kolaborasi antar siwa lebih ditekankan pengembangannya daripada kompetisi

5). Nilai-nilai seperti fairness, saling menghormati dan kejujuran adalah bagian dari pembelajaran tiap hari baik di dalam kelas atw luar kelas

6). Para siswa diberi keleluasaan untuk mempraktikan perilaku moral melalui kegiatan pembelajaran untuk melayani (service learning).

7). Disiplin kelas dan pengelolaan kelas dipusatkan pada pemecahan masalah daripada dipusatkan pada penghargaan dan hukuman.

8). Model lama berupa pendekatan berbasis guru yang otoriter tidak pernah lagi diterpakan di ruang kelas, tetapi lebih dikembangkan suasana kelas yang demokratis dimana para guru dan para siswa melaksanakan semacam pertemuan kelas untuk membangun kebersamaan, menegakan norma-norma yang disepakati bersama, serta memecahkan persoalan bersama-sama (Samani, 2011).

Berdasarkan pemaparan di atas, maka dapat disimpulkan, bahwa model yang dapat digunakan dalam praktik pendidikan karakter di masyarakat khususnya di Institusi Pemerintah, Institusi Sosial, dan di Ruangruang Publik yaitu melalui proses pengajaran, keteladanan, pembiasaan, pemotivasian, serta penegakan aturan.

\section{PENUTUP}

Simpulan akhir dari makalah ini, bahwa Karakter adalah cara berpikir dan berprilaku yang menjadi ciri khas tiap individu untuk hidup dan bekerjasama, baik dalam lingkup keluarga, masyarakat, bangsa, dan negara. Nilai-nilai dalam pendidikan karakter berbasis masyarakat dapat bersumber dari agama, Pancasila, budaya, dan tujuan pendidikan nasional. Adapun pengembangan Model yang dapat digunakan dalam praktik pendidikan karakter di masyarakat khususnya di Institusi Pemerintah , Institusi Sosial , dan di Ruang-ruang Publik, yaitu model pendidikan melalui proses pengajaran, keteladanan, pembiasaan, pemotivasian, serta penegakan aturan.

\section{DAFTAR PUSTAKA}

Aan Hasanah. (2013). Pendidikkan dalam Perspektif Karakter. Bandung: Insan Komunika.

Amirulloh Syarbini. (2017). Pendidikan Karakter Berbasis Keluarga Studi Tentang Model Pendidikan Karakter dalam Keluarga Perspektif Islam. Yogyakarta: Ar-Ruzz Media.

Bagong Suyanto. (200511). Pendidikan Berbasis Masyarakat:Prasyarat yang Dibutuhkan". Jurnal Edukasi, Vol I, No 1.

Dharma, d. (2011). Pendidikan Karakter, Kajian Teori dan Praktik di Sekolah. Bandung: Remaja Rosdakarya.

H.AR Tilaar. (2000). Paradigma Baru Pendidikan Nasional. Jakarta: Rineka Cipta.

Haris. A.S. (2001). Pengembangan Sekolah Melalui Partisipasi Masyarakat: Sebuah Kajian Operasional Tingkat Sekolah. jogjakarta: Universitas Jogjakarta.

Masnur Muslich. (2011). Pendidikan Karakter, Menjawab Tantangan Krisis Multidimensional. Jakarta: Bumi Aksara.

Samani, M. (2011). Konsep dan Model Pendidikan Karakter. Bandung: Remaja Rosdakarya.

Saptono. (2011). Dimensi-dimensi Pendidikan Karakter, Wawasan, Strategi, dan Langkah Praktis. Jakarta: Erlangga.

Syamsul Kurniawan. (2013). Pendidikan Karakter: Konsepsi dan Implementasi Secara Terpadu diLingkungan 
Keluarga, Sekolah, Perguruan Tinggi dan Masyarakat. Yogyakarta:: Ar-ruzz Media.

Umberto Sihombing. (2001). Konsep dan Pengembangan Pendidikan Berbasis Masyarakat. Yogyakarta: : Adicita Karya Nusa.

Wahyudin Sumpeno. (2009). Sekolah Masyarakat; Penerapan Rapid-TrainingDesign Dalam Pelatihan Berbasis Masyarakat. Yogyakarta: Pustaka Pelajar.

Zubaedi. (2006). Pendidikan Berbasis Masyarakat. Yogyakarta: Pustaka Pelajar. 